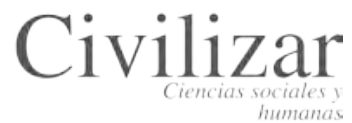

ISSN 1657-8953 e-ISSN: 2619-189X

\title{
Intellectual Property and Innovation Process under Goal 17 of Sustainable Development*
}

\author{
Propiedad Intelectual y Procesos de Innovación en el marco del \\ Objetivo 17 de Desarrollo Sostenible \\ Gabriela Antošovás \\ Jorge Cifuentes Valenzuela
}

* This review article was supported by Czech Science Foundation, project No. GA16-01383S "Complex theoretical model for estimating a reasonable financial compensation for employee innovations.

$\S$ Ph.D. in Regional and Social Development, Czech University of Life Sciences. Research Fellow at the University of Economics and Assistant Professor at The Private University College of Business, Prague, Czech Republic.

E-mail: antosova@vso-praha.eu

(iD) $0000-0001-5330-679 \mathrm{X}$

Ph.D. Doctor of Business Administration School of Economy and Administration, ESEADE. Director of the Business Administration Program at Corporación Universitaria Minuto de Dios - Uniminuto, Bogotá, Colombia. E-mail: jcifuentes@uniminuto.edu

(iD) 0000-0001-9945-6312

Cómo citar/How to cite:

Antosova, G., y Cifuentes-Valenzuela, J. (2019). Propiedad Intelectual y Procesos de Innovación en el marco del Objetivo 17 de Desarrollo Sostenible. Civilizar: Ciencias Sociales y Humanas, 19(37), 117-130. doi: 10.22518/usergioa/jour/ $\operatorname{ccsh} / 2019 \cdot 2 /$ a10

Recibido: 19/07/2019

\section{Abstract}

This paper presents a conceptual discussion focused on the basic vision of science and technology, which is the primary purpose and reference framework of the produced United Nations' documents and the Sustainable Development Goals (SDGs) of the 2030 Agenda. The most important intention and the objective of these documents is the technology transfer, which carries a risk of not recognizing other technological options-such as eco-technology-and the limited role representing science and innovation in the achievement of these Sustainable Development Goals. We focused on the broader aspects of international patent law approaches that approximate to incentives of technological transfer and innovation process. This article contributes to the theoretical overview of patent law in the application process of intellectual property use in the international context. In conclusion, we discussed, according to the literature review, the possibility of maintaining the environment by considering technological transfer and innovation process as solutions for world disasters. Sustainable development goals are proposed for the same prevention, which should be clear for every country in the world.

\section{Keywords}

Patent law, sustainable development goals, intellectual property, employee inventions, partnership.

\section{Resumen}

En este documento se presenta un debate conceptual centrado en la visión básica de la ciencia y la tecnología, la cual es el propósito principal y el marco de referencia de los documentos producidos al respecto por las Naciones Unidas y los Objetivos de Desarrollo Sostenible (SDG) de la Agenda 2030. La intención y el objetivo de aquellos documentos es la transferencia de tecnología, que conlleva el riesgo de no reconocer otras opciones tecnológicas -como la ecotecnología- y el limitado papel que representan la ciencia y la innovación en el logro de estos Objetivos de Desarrollo Sostenible. Nos centramos en los aspectos más amplios de los enfoques del derecho internacional de patentes que se aproximan a los incentivos de la transferencia tecnológica y el proceso de innovación. Este artículo contribuye a la visión general teórica del derecho de patentes en el proceso de aplicación del uso de la propiedad intelectual en el contexto internacional. En conclusión, discutimos, de acuerdo con la revisión de la literatura, la posibilidad de mantener el medio ambiente considerando la transferencia tecnológica y el proceso de innovación como soluciones para los desastres mundiales. Se proponen objetivos de desarrollo sostenible para la misma prevención, que deben ser claros para todos los países del mundo.

\section{Palabras Clave}

Derecho de patentes, objetivos de desarrollo sostenible, propiedad intelectual, inventos de empleados, asociación. 


\section{Introduction}

In this article we provide a sociological review of several documents aiming to the vision of science and technology in the framework of Sustainable Development Goals (SDGs) of the Agenda 2030. Moreover, we review international legal framework of patents, intellectual property, and the process of technological transfer and innovation.

Guerrero (2014) described an outstanding role of technological transfer among less industrialized countries for spurring the development, where a mechanism must be settled to create a material equalization between the two parts of the contracts, and ultimately to spread out all benefits to the entire society. According to Almario (2018, p. 7), technology is understood as "the ability to produce results that materialize in goods and services, through the application of scientific knowledge and adaptation to the social environment of procedures, instruments and equipment from the national and international scientific community." In this sense, technology behaves like a sellable product: it has use and exchange value and restricted circulation information, it is intangible because it is knowledge, it is not extinguished by its use, and it demands fast application so it does not become obsolete and does not cover its costs (Almario, 2018).

Sectors and geography have expanded the application ground for technological transfers. A suitable ground for implementing such strategies are high-end technology firms, which provide fast development environments and constant pressure for innovating and reaching cutting-edge technologies and processes. Such a relevant role of sustainability stems from high tech revolution and in consequence, there are high expectations about developments and open routes deriving from this technological sector towards the whole economy. In the business environment, technology transfer is a component of its lucrativeness and development.

The technology firms display a set of recognizable attributes (Balkin \& Gomez-Mejia, 1984), namely:

- Products at the cutting edge of technological level,

- organizational highlighting of $R \& D$ process,

- continuous innovations happening frequently at frequent intervals,
- rotation and continuous turnover of R\&D personnel,

- geographic concentration of high technologies, and

- high mortality rates among firms due to intense competitive pressure.

On September 25, 2015, the United Nations General Assembly issued the Resolution (A/70/L.1) Transforming Our World: the 2030 Agenda for Sustainable Development. The document is divided into five main parts: Preamble and Definitions, Declaration, Sustainable Development Goals and targets, Means of implementation and the Global Partnership, and Follow-up and review. The core of this document is the definition of 17 Sustainable Development Goals and their 169 main targets. Under the section focused on the essence of the implementation of the Agreement (2015), an endeavour to attain the technology facilitation mechanism has been initiated based on the cooperation of multi-stakeholders among the member states, civil society, the private sector, scientific and academic spheres, United Nations bodies and other stakeholders.

This cooperation will be included in the task team's responsibilities. The team will deal with science, technology, and innovation for the achievement of the Sustainable Development Goals, including the online platform. Albeit Target 17.6 and the technology facilitation mechanism have already been mentioned in science and innovations, the main focus of this document lies in technology transfer-although science and innovation are not perceived as the key idea, but as a part of technology spillovers (d'Andria, 2016b). Imaz \& Sheinbaum (2017) point to the vision of the entire framework of Sustainable Development Goals, specially (thanks science, technology, innovation) those of technology transfer.

The introduction of technology transfer (Polenakovik \& Pinto, 2010) is the primary source of the attainability of the Sustainable Development Goals. Risks were focused on three levels that have been a matter of discussion historically (Imaz \& Sheinbaum, 2017):

1. Positioning the power outside of the civil and political decision-making is power situated under the conceived science and technology. 
2. Ignoring that the environmental limits to the intensification of the climate change cannot be resolved by technology transfer.

3. Neglecting the role of social sciences and the humanities and other knowledge sources or minimizing the role of other eco-technological approaches to the attainability of the Sustainable Development Goals.

The fact that science and technology are the power which - outside of the civil and political decision-making power - enables interventions and changes the world needs to be accepted as an inevitability (Ozolina, Mitcham, \& Stilgoe, 2009).

The perspective of science is remarkable, even from the past, when it became the predominant reflection accentuating the thoughts of scientists such as Copernicus, Kepler, Galileo Galilei or Newtonian philosophy which gave us nothing less than the coordinates for constructing the coordinates of reality (Thiher, 2001). Although mathematics seems perfect and eternal, the ideas of Plato and Descartes, who enriched knowledge with the truth, need to be supplemented with human construction. On the other hand, science uses man's being for understanding the complex and chaotic world that surrounds us (Vico, 1984). Finally, one may also mention Herbert Marcus, who explained that: "Growth is not just a neutral term, as it moves the world thanks to specific objectives and these objectives are defined with the possibility of enhancing or improving human conditions of existence."

However, technology does not dominate nature, but it will lead the path of humanity and not viceversa. At present, the human relationship with nature and its ways or concepts leading to development are still to be assessed. We can agree that scientific knowledge is a social construction. This fact is not in conflict with the emphasis placed on the support and development of science, technology, and innovation. The society aims at epistemology examining the characteristics of the source and the importance of knowledge, which can help explain the challenges the world faces. These challenges are not only scientific and technical, but, above all, they are "civic". For this reason, science, technology, and innovation offer huge opportunities for sustainable development by the reciprocal interconnection of science, culture and traditional knowledge, which we can understand as a "win-win" situation (D. d'Andria \& Savin, 2018).
The innovation system may be understood as a personal effort (d'Andria, 2016a). The unknown in this formula may be represented by "natureman". "Lévi-Strauss drew attention to the fact that it is important to ask questions in connection with proper science. Some of these questions may reflect on this observation of his: Bifurcated purpose of resources (i.e. consumption and development)" (Saadi \& Djebabra, 2015). How can we support social "welfare" with limited resources? Or how can we assess human development and reduce environmental degradation? These questions are part of international discussions about sustainable development, but they are far from being resolved. The essence of knowledge is that these questions and answers are regionally diverse, and states are trying to overcome them through transfer of technologies.

Various orientations leading to the attainment of the sustainable development goals have been identified from the presented theoretical basis as well as the study of documents and literature. These orientations have been divided into five key areas. Table 1 presents the importance that the SDGs attain in its implementation across the five key areas.

1. Technology transfer. To confirm that scientific and technological development is accessible to an extensive user environment.

2. Eco-technology. It is defined as a benefit of the technological ideas of ecosystem management, which is based on a deeper understanding of the underlying principles of natural ecosystems. Eco-technology extends to the transfer of these principles into the management or control of these ecosystems (Straškraba, 1993; Funtowicz \& Ravetz, 1995; Ortiz-Moreno et al., 2015).

3. Inter-disciplinarity. (scientific approaches defined in the 2004 National Academy Report). A method research that, through areas of research practice, broadens the fundamental understanding or management of problems that extend across various disciplines. This type of research can be conducted in groups or individually and includes information, data, techniques, instruments, perspectives, concepts, and theories of two or more disci- 
plines or spheres of specialized knowledge (Kaufmann, 1995; Rotmans \& Loorbach, 2009; Scholz \& Steiner, 2015).

4. Socio-economic policy. It refers to the analytical component of public policies, which are not a necessary part of technological innovation and technology transfer.

5. The feasibility of the vision. This area presented in the 2030 Agenda does not reach $100 \%$ conformity or consensus, but it is scientifically debated across the 17 global Sustainable Development Goals and their gradual implementation.

For example, SDG 5, which aims to achieve gender equality and empower all women and girls, was considered as the only goal of the 17 to be the least important in three areas in the context of the implementation, namely technology transfer, eco-technology, and the feasible vision. Subsequently, the SDG 1, 4, 5, 10, 16 and 17 were considered less important in the same areas. These targets

Table 1

Level of importance attained by the SDGs in their implementation across the five key areas

\begin{tabular}{|c|c|c|}
\hline Area of SDG 17 & +++ & + \\
\hline $\begin{array}{l}\text { Technology transfer } \\
+++(8 \text { out of } 17) \\
+(6 \text { out of } 17)\end{array}$ & $\begin{array}{l}\text { Ensuring healthy lives and quality living } \\
\text { conditions for all (3); ensuring availability } \\
\text { and sustainable management of water } \\
\text { and humanitarian aid for all (6); ensuring } \\
\text { access to affordable, reliable, sustainable } \\
\text { and modern energy for all (7); building } \\
\text { resilient infrastructure, promoting } \\
\text { inclusive and sustainable industrializa- } \\
\text { tion and innovation (9); making cities } \\
\text { and human settlements inclusive, safe, } \\
\text { resilient and sustainable (11); ensuring } \\
\text { sustainable consumption and production } \\
\text { patterns (12); taking urgent action to } \\
\text { combat climate change and its impacts } \\
\text { (13); as well as conserving and using } \\
\text { oceans, seas and marine resources for } \\
\text { sustainable development (14). }\end{array}$ & $\begin{array}{l}\text { Ensuring healthy lives and } \\
\text { quality living conditions for all } \\
\text { (3); ensuring availability and } \\
\text { sustainable management of water } \\
\text { and humanitarian aid for all (6); } \\
\text { ensuring access to affordable, } \\
\text { reliable, sustainable and modern } \\
\text { energy for all (7); building resilient } \\
\text { infrastructure, promoting inclusive } \\
\text { and sustainable industrialization } \\
\text { and innovation (9); making cities } \\
\text { and human settlements inclusive, } \\
\text { safe, resilient and sustainable (11); } \\
\text { ensuring sustainable consumption } \\
\text { and production patterns (12); } \\
\text { taking urgent action to combat cli- } \\
\text { mate change and its impacts (13); } \\
\text { as well as conserving and using } \\
\text { oceans, seas and marine resources } \\
\text { for sustainable development (14). }\end{array}$ \\
\hline $\begin{array}{l}\text { Eco-technology } \\
+++(5 \text { out of } 17) \\
+(6 \text { out of } 17)\end{array}$ & $\begin{array}{l}\text { Ending hunger, achieving food security } \\
\text { and improved nutrition and promoting } \\
\text { sustainable agriculture (2). Further, it } \\
\text { is necessary to protect, restore and } \\
\text { promote the sustainable use of terres- } \\
\text { trial ecosystems, to manage forests } \\
\text { sustainably, to combat desertification, } \\
\text { and to halt and reverse land degradation } \\
\text { and to stop biodiversity loss (15); further } \\
\text { ditto SDG } 6,7,12 \text {. }\end{array}$ & SDG $1,4,5,10,16,17$. \\
\hline $\begin{array}{l}\text { Inter-disciplinarity } \\
\text { Socio-economic policy }\end{array}$ & Fully meets all the 17 global goals. & Not containing. \\
\hline $\begin{array}{l}\text { Feasibility of the vision } \\
\begin{array}{c}+++(10 \text { out of } 17) \\
+(6 \text { out of } 17)\end{array}\end{array}$ & $\begin{array}{l}\text { SDG } 1,2,3,4,8,10,12,15,16,17 \\
\text { (1) End poverty in all its forms. }\end{array}$ & SDG 5, 6, 9, 11, 13, 14 \\
\hline
\end{tabular}

Note: high importance (+++) and low importance (+). Source: author's elaboration 
include reducing disparities across states, promoting peaceful and inclusive societies for sustainable development as well as providing access to justice for all and building effective, accountable and inclusive institutions at all levels. However, these goals should be implemented with high importance in the areas of inter-disciplinarity, socioeconomic policy (Ratiu \& Anderson, 2014), and the feasibility of the vision.

A fascinating stream of empirical and theoretical approaches, mainly those related to psychology and behavioural economics, asserts that intrinsic motivation not related to economic rewards are the most powerful engine for creativity and innovation within firms. Band et al. (1994) assert that there are more intangible rewards for employees such as the desire for personal improvement, the simplification of work, and the enhancement of participation in company decisions (Jaakson \& Kallaste, 2016).

Global character and deepness of changes complexify the scientific-technological revolution (Richta, 1969), changing not only the economic perspective of the actual world but the whole social and cultural way of human existence. These changes are significant, especially in the assessment criteria that emerged in society, formed based on capitalist industrialization as irrefutable canons. How easy is, for example, for the working class to understand the category of work that conditions innovation processes? In addition, production and innovation are predominantly based on machine operators: where, however, are currently the limits of creative work? Can a millstone be found between a patent and a human being's own activity? Similarly, we could ask ourselves the following questions: what is growth, how to understand innovation, wealth, and sustainability. The scientific and technological revolution in its first stage has led to the emergence of new fields of human activity while maintaining traditional manufacturing industries, or their minor changes. In the second phase, since the 1970s, this revolution has begun to change almost everything that has so far formed the material basis of being. The advancement of microelectronics, biology, and new materials has created new perspectives for humans, which cannot be imagined at present.

On the other hand, innovative processes leave room for serious threats to further revolutionary development. It is not just about destroying humankind in a thermonuclear conflict but also about the possibility of negatively influencing humans through genetic engineering (Doucouliagos \& Laroche, 2010), the build-up of civilization diseases, and the danger of human's conflict with the irrationality of technology. The irrationality brought about by the scientific and technological revolution is directly embedded in their character. Traditional societies, not only in the sense of pre-capitalist civilizations but also social forms arising from the Second Industrial Revolution, are experiencing problems with the emergence of several "inorganic" phenomena in the way individuals are involved and the functioning of social structures.

The concentration of change in science and technology through technology transfer raises the need to rebuild social systems and their behaviour so that new phenomena and processes can be incorporated into humans' lives. Diversity-which implies disruption of the functions of social systems-is the result of the internationalization of the contemporary world economy. Transfers of new technologies and related changes in the skills of the workforce, the nature of the work, the position in the social division of the work of individual professional groups, the necessity of transformation of the distribution mechanisms and of the copyright disputes complicating the way of life of "traditional" or "modern" social organizations (Isabella, 1990). Social mechanisms are constantly exposed to environmental pressures that "transplant" non-organic phenomena and processes in the internal environment of the society, but before the organism fully accepts and strikes a balance, there are others.

Technical and technological changes are already starting to crumble the existing production base. The production is going to be conducted in the warehouse but, at the same time, information and production systems are beginning to enable production to fit the customer requirements. Suppliers are responsible for the functionality of the mounted sub-parts, which puts new demands on producer co-operation and coordination. This pressure is being developed for innovators and patent data makers (Brander \& Zhang, 2017). Today's 3D printers can print functional weapons (Varadzin, 2013). It is only needed to have the appropriate 
program on the floppy disk and fold it precisely. Information networking has completely separated the design site from the point of production. The more the world is integrated, the greater the importance of control over these networks.

\section{Technology Transfer and Its Legislation in an International Context}

The transfer of technology has different forms: acquisition of patents or licenses (Jiang \& Iii, 2010); mergers, acquisition or joint-ventures operations; acquisition of machines, equipment and components; reverse engineering; analysis of information contained in the catalogues of products, publications or presented at congresses, and hiring technicians from competing companies (Almario, 2018). The oncoming evolution of the intensive interaction between innovation transformation-such as technology transfer in the application of the ownership right transfer between the employer and employees (Aerts, Kraft, \& Lang, 2015), that is, the innovation creators (Adhikari, Choi, \& Sah, 2017)-and their practitioners requires monitoring of legislation that directs the productivity and potential economic consumption (Irani, 2010). Internationalization (Archibugi \& Michie, 1995) of the whole system starts showing an upward trend in obtaining the right to apply economic value on a global scale (Molero \& Garcia, 2008). In the same way as the issues of patents or innovations are being regulated (Iammarino, Sanna-Randaccio, \& Savona, 2009), the legislation for equitable remuneration (Rose \& Manley, 2010) of their creators is becoming considerably significant. The introduction of patent boxes survey made a scale of engaging tax competition of patent incomes (Griffith, Miller, \& O'Connell, 2014).

According to the World Intellectual Property Organization, a patent is a legal authorization that grants its owner the exclusive right to control the use of an invention, as defined in its claims, within a geographical area and a limited period (20 years), preventing third parties from manufacturing, using, selling or offering the invention for sale without authorization (WIPO, 2018). Through the arrangement of Strasbourg on October 7, 1975, the International patent classification was adjusted to 8 sections designated by capital letters (A to $\mathrm{H}$ ); the title of each section indicates its content. In consequence, transfer technology considers as an exchange of information, intellectual property rights between and among government, academic, or industry laboratories to facilitate further research and commercialization.

This significant fact appears to be already much more complex and heterogeneous in the organization of innovation processes; the on-going interaction between the employee and the employer, through technology transfer, does not result, by far, in mutual enrichment (Essop \& Hoque, 2018). Therefore, the issue of equitable compensation (Kabadaki, 1994) or additional remuneration is very current and is being increasingly discussed also from the aspect of the impacts associated with the achievement of the Sustainable Development Goals under the 2030 Agenda. This on-going need to resolve or achieve or set an equitable remuneration system for the application of the right to transfer technological ownership is inevitable for these challenges. The idea of mutual enrichment in the technology transfer also encompasses the growing trend of related costs, accelerated obsolescence and out-datedness of the already created patents or innovations. Moreover, importance also needs to be placed on the combination of entrepreneurial activities or mergers, as well as external knowledge of the currently existing patents and finally, in the process of learning the technologies. In fewer and fewer companies it is possible to find a basis in all inputs and assets of the immediate environment. In other words, the national system of innovation is less and less "national" because it is more and more included in the elements of international affairs and its players (Molero \& Garcia, 2008). How we conclude and understand the full meaning of patentability more internationally?

Necessarily we must focus on the differences among legislations regulating technology transfer rights applied by employers in the international context ("Jurisdictions," 2017). In France, employee inventions are mainly governed ("Patent Law-France," 2017) by legal regulations of Articles 611-7 of the French Intellectual Property Code (IP Code). These laws regulate the procedure only for employers, particularly in the absence of contractual arrangements, such as collective agreements, corporate agreements or employment agreements, which favor more rights of the employer.

The system of ownership and determination of the ownership rights concerning the additional compensation or equitable remuneration varies 
widely, specifically according to the classification of inventions into three groups subject to the employee inventions defined by the IP Code. The German Act on Employees' Inventions (AEI Law) is a valid regulation of the German legislation supplemented by relating regulations aimed at remuneration ("Deutsches Patent und Markenamt," 2017). These regulations include a detailed scheme of remuneration guidelines relating to employee inventions. This Act also regulates some of the legal obligations of employers and the rights of employees. All companies employing inventors, founded in Germany, must abide by these laws and their amendments in accordance with the German Act on Employees' Inventions.

Article 64 of Regulation No. 30/2005 of the Act on Employee Inventions is the valid legislation and sets out a comprehensive system of ownership of employee inventions including the remuneration system in Italy ("Patent law in Italy," 2017). The Act on Industrial Property of June 2000 regulates the performance of duties by an employee, as well as the application of the right to the invention or the transfer of ownership to the employer in Poland unless otherwise agreed by the parties involved ("Postępowanie sporne - Urząd Patentowy Rzeczypospolitej Polskiej," 2017).

Spain applies slightly different procedures, which are regulated by the Spanish legal regime on employee inventions (Articles 15-20 of Act 11/1986 governing patent matters). This legislation (Oficina Española de Patentes y Marcas, n.d.) governs the basic principles of the patent system, including the transfer of rights and remuneration, as well as the obligations and rights of both parties. The rights granted to employees are imperative, and therefore, any waiver of these rights is inadmissible. In disputes relating to inventions or application of ownership, a request must be filed with the Patent and Trademark Office at first. Disputes relating to this matter are then resolved by a three-member commission appointed by the said Spanish Office, where one member of the commission is appointed by the employee and the second by the employer. If the parties do not agree with the proposed settlement provided free of charge, it is necessary to refer this dispute to court.

Cases from the Netherlands do not mention any specific obligations of employees relating to their inventions. The employee's obligation is lim- ited to informing the employer that the invention has been created and to confidentiality, based on the employee's obligation to act in the best interests of the employer. Special provisions may be set out in the contractual arrangements voluntarily. In other areas, the obligations concerning the remuneration of employees in the context of the application of the rights connected with technological progress are more and more varied.

As to the United Kingdom, it applies in general that inventions created by employees within their regular working duties automatically belong to the employer. The employer, therefore, is entitled to exploit the invention at his discretion (Intellectual Property Office et al, 2017), without having to exact consent from the employee or deal with the claim for additional compensation. However, if there is a dispute about the patent ownership and the patent is subject to control, which is to say in the instance of recognized extraordinary enrichment of the employer resulting from this patent, an employee may be paid additional compensation. In this case, the ownership right or identity of the created patent shall be decisive; the Patents Act 1977 refers explicitly to "the actual inventor of this patent."

The definitions of ownership rights in the United States of America are governed by the future exploitation of the created inventions to avoid subsequent complications in the transfer of the rights for the duration of the employment process. In compliance with the common rules of the applicable legislation, the ownership rights in the USA are allocated in line with the independence of the employees in creating special-purpose innovations or technological inventions (United States Patent and Trademark Office, 2017). The legislation governing the exploitation of inventions providing for the contractual arrangement between the employer and employee is increasingly being applied. Obligations relating to the exploitation of employee inventions are regulated in the Civil Code in Russia ("Russian Federation. Patent Law of Russian Federation No. 3517-1 of September 23, 1992 (as amended by Federal Law No. 22-FZ of February 7, 2003)," (n.d.)), where the general regulatory framework for employee inventions and some contractual relations are laid down.

Concerning Japan, the rights relating to an invention of an employee are governed by Section 35 of the Patent Act Patent Act ("Japan: Patent Act 
(Act No. 121 of 13 April 1959, as amended up to 2006," n.d.). The original legislation favored the employee in terms of exercising his/her rights when the ownership transfer was carried out based on laborlaw regulations or contractual arrangements where the employee was granted reasonable remuneration. Depending on the share exploitation, the employer was also able to transfer the patent to a third party. The Amendment to the Act, which came into force in 2016, no longer favors the employee; the right inherently pertains to the employer, if regulatory provisions or contractual arrangements have been agreed upon between the two parties in advance.

In this case, the employer is not required to exact consent to transfer ownership rights and is not even required to obtain the consent of the other joint owners because she/he is the rightful owner of the created patent. If this agreement has not been proven in advance based on internal directives, then the employee is the inherent owner, as it used to be before the Amendment to the Act. Regarding appropriate remuneration, the Amendment provides that this remuneration is included in the normal economic profit or monetary remuneration. This remuneration includes, for example, stock options, salary increase, paid holidays, or the opportunity of studying abroad. Finally, this Amendment to the Act also appoints the authority established under the Ministry of Economy, Trade, and Industry as the decisive body in determining the appropriate remuneration for employee inventions. The governing guidelines that determine and enforce appropriate remuneration were published in 2016, but these procedures are not legislatively enforceable.

In Hong Kong, the situation is very similar to the Japanese system before the Amendment to the Act (Intellectual Property Department, Hong Kong, 2017). The employer is fully entitled to use the created patent without providing the employee with additional compensation, as the employee invention was created during work duties, while the employee's consent to the further transfer is not even considered. However, if the invention or patent was created after June 20, 1997, it is considered by the Hong Kong High Court to be a non-gainful benefit of the employer, where the Court must take into account the size of the enterprise, in which the patent was created. After the Court's decision, an employee may be provided with additional remuneration.
This determination applies both to long-term patents (20 years) and short-term (8 years) patents in Hong Kong. The same applications relate to other forms of protected ownership provided in different countries or territories addressed by this Court.

Over the years, China has been developing, somewhat partially and superficially, the legal framework governing employee inventions and related remuneration ("State Intellectual Property Office of The P.R.C.," 2017). This framework consists primarily of the Patent Act regulating patents and inventions, and the Act on the Support of Transformation of Scientific and Technological Results that deals with non-patented inventions (service inventions, for which employers and employees agreed not to use the patent protection).

We could also mention the examples of Latin America, which are different regarding other continents. In Mexico, these relations are regulated by the labor law that specifies the employee's obligations who creates inventions at the expense of the implementation of his/her activities in favor of the employer ('Intellectual Property Rights Information \& Assistence, 2019).

Similarly, in Colombia, the main rules that regulate the process are Law 463 of 1998, which approves the Patent Cooperation Treaty (PCT) and its regulations, Decree 2153 of 1992, by which the Superintendence of Industry and Commerce is restructured, and others provisions are dictated. Other ordinances are Decision 486 of 2000 of the Andean Community of Nations, CAN; Commercial Code (C.C. - Decree 410 of 1971), and Inventor's Manual of the Superintendence of Industry and Commerce.

The classification of the normative structure is Patents (Invention), Industrial Designs, Trade Names and Trademarks, and Traditional Knowledge. The norm states that the invention should be understood as the creation of something new to solve an existing technical problem. An invention is the result of creative activity, when it does not derive clearly from the state of the art, by the combination of methods or procedures, or by the obtained industrial result (C.C. Art. 536). Likewise, the norm clarifies that an invention is the result of creative activity with incentive value, which is susceptible to industrial application and patentable (C.C. Art. 534). Considering that an object is useful for manufacture procedure or in each industry, 
including agriculture, it should be susceptible to the industrial application (C.C. Art. 537). Regarding an entitlement, the invention carried out by an employee or a research contractor belongs to the employer (C.C. Art. 539). The same principle applicants who achieved the inventions by a noncontracted researchers, but who uses data or other means used in his job; in that case, the employee has the right for compensation. The duration of a patent of invention is 20 years from the date of presentation; after the 20 years, the design will be public domain (C.C. Art. 553). The patents granted in Colombia are only protected in the country.

The main rules in Chile related to Intellectual Property are Law No. 19039 of Industrial Property, Law No. 17336 of Intellectual Property (Copyright), and Law No. 19342 on Rights of Breeders of New Plant Varieties. Law No. 19039, published in the Official Gazette on January 25, 1991, and its regulations-Supreme Decree No. 177, published on September 30 of the same year-contain the norms applied to industrial property rights of the trademark type, invention patents, utility models and industrial designs (Instituto Nacional de Propiedad Industrial, 2018). The Title VI of the latter Law settles the entitlement of inventions pointing out that the registration and the eventual industrial property rights belong to the employer, especially in cases with creative activities of employees with a labor contract and outcome-based contract with invention functions (Art. 68). Besides, inventions achieved by employers with non-creative activities will belong to the employer under the condition that the former receives some benefit inside the firm (Art. 69). In the case that the employee does not use the firm's information or data, the employee can claim the registration without the realization of inventions or creative activities. Finally, the entitlement of the invention and creative activities of employees contracted under a dependent or independent rapport by universities or research entities will belong to these institutions (Art.70).

Brazil is the country with the most patent applications in Latin America. Innovation and patenting processes are regulated by Law No. 9279 of May 14, 1996 (INPI, 2018). The Chapter 1 of Title I rules that the author of the invention or a model of utility will be given the right to obtain the patent guaranteeing the property, under the conditions defined in the Law above (Art. 6). However, the invention and the utility model belong exclusively to the employer during the term of a labor contract, having as purpose a research or an inventive activity, or in the case of being a consequence of services related with the labor contract of the employee (Art. 88). Retribution for the labor related to the article mentioned above is bounded by the adjusted salary (Art. 88, number 1). However, the employer can concede to the employee, the author of the invention, a share in the economic benefits derived of exploitation or the patent through a bargain with the interested employee (Art 89).

The notification made by Brazil to the World Trade Organization (WTO) under Article 63.2 of the TRIPS Agreement stipulates: "Articles 46 to 49, 56 and 57 regulate the nullity of patents, Article 118 regulates the nullity of industrial designs, articles 165 to 167,173 to 175 regulate the nullity of the trademarks, article 206 contains provisions for the 'secrecy of justice' and articles 207 to 210, contain general provisions relating to civil actions related to the violation of the rights of intellectual property. These procedures are carried out through the Instituto Nacional da Propriedade Industrial, INPI, a self-sufficient public body in Brazil created in 1970 under the Ministry of Development, Industry and Foreign Trade (INPI, 2018).

Achievement of Technology Transfer Applying the Public-Private Partnership [T1]

The inclusion of the Public-Private Partnership (PPP) projects is an essential factor in the development of developing countries and emerging markets because it generates synergy effects. In most countries where development has already been achieved based on PPP, the population is cautious concerning the private sector. This caution relates particularly to projects aimed at the development of infrastructure of all kinds and the achievement of technology transfer. Innovative projects, which have been implemented in adverse natural conditions, confirmed that the large risk had spread. Moreover, from the employees' point of view, the new technology could crowd out the workforce, and in consequence, the workers' attitude could lead to distrust innovations. Despite resistance, profit share can communicate to employees the will of the firm to compensate for the risks. Thus, profit share could operate as a risk premium that pays the risk of technology incorporation to the workers so that they can become an asset in the process of modernization. 
Moreover, some employees interact with customers and can detect their preferences as strategic information for the firm (Aerts, Kraft, \& Lang, 2015). Benefits of profit share could be combined with the curve of learning approach, which is provided in the long process of adaptation to work post. The employees learn the task and progressively can provide information for optimizing the execution of process and operations and can suggest information for product improvement.

To prevent risks, the essential part of these projects also needs to be part of the civil society, where the achievement of the SDGs through the PPP projects should be based on their own implementation process initiatives. In this context, Zapatrina (2016) has already commented on the mutual understanding founded on excellent communication, as a mandatory part of the SDG achievement structure, specifically via the technology transfer on the basis of these projects. The initiators are to explain to society "face-to-face" the reasons for adopting their submitted proposals.

International Financial Institutions (IFIs) also play a fundamental role in these projects due to the support of social participation. These institutions have taken an interest in becoming part of such projects for the following reasons: their participation will always be guaranteed to the private partner regardless of corruption and political instability; for the purpose of implementing high quality projects, including their preparation, they will be able to reach an understanding with international business partners; they will recommend the development of project documentation as a way to arouse interest in the private sector, namely thanks to the loans to any of the winners from their ranks; and they will teach the participation of the public sector during the actual project preparation on the "learning organization in action" basis. Support of the theory positive impacts in organizational performance explained survey (Zhang \& Morris, 2014).

The idea of a global project may be considered as the basis of the extended development of the implementation mechanism of the SDGs. This base includes the creation of an innovation model for developing countries; technical assistance is applied in the context of the new 2030 Agenda. This model should meet the following criteria: to stimulate governments of developing economies to integrate
SDGs into their national strategies and strategic plans (Edgar, Abouzeedan, Hedner, Maack, \& Lundqvist, 2013), and to adopt a responsible policy in this aspect (Fabbri, 2016; Oliveira, 2015); to arouse the interest of the private sector on a global scale, and direct their strategies, including the management of their activities, to the assistance of SDG implementation not only in their own countries but also in developing economies hit by the social and economic pressures of global impacts.

The main problematic issues related to the achievement of the SDGs in developing economies are, particularly, the lack of knowledge of public authorities and their capacity to accomplish those Goals via the PPP projects. Further, the governments do not have a model mechanism set adequately to the established PPP system for the creation and innovation of the existing infrastructure, and not even the budgetary policies are strong enough to finance the PPP projects. The plan is based primarily on the technical support of programs in the context of the 2030 Agenda, which must be directed at the adaptability of the already existing PPP model, based on SDG demands. Moreover, the establishment of essential institutions is also seen as necessary as is the improvement of the capacities to execute the SDG measures with the active participation of local experts and scientists during the entire implementation process.

\section{Conclusion}

At present, the integrity of the contemporary world is immense. The internationalization of relations between nations is growing based on the improvement of communication systems (Madlock \& Sexton, 2015; Nepal, Park, \& Son, 2006), transportation, constant specialization and cooperationincreasing dependence on one another-, leading to the gradual decomposition of autocratic ideas, and to the advance of the idea of integrity. Understanding integrity means accepting the real conditions of humankind being in control of already-effective forces that can kill humans in a global disaster. That is why Sustainable Development Goals are set in the integrity of nations, which is the essence of a new perspective. However, the efforts of the United Nations to "de-ideology" contemporary relations, for example, to replace the real-world view with unrealized premises and origins, leads to the loss of truth. 
The fact is that every such view of the world, albeit often objectives of the self-intended one, has failed without the incorporation of all the powers of the world. Here again, we can bring different solutions to the problems of developing countries or fail to meet the conclusions on the protection of the world's natural environment (Maas \& Rosendaal, 2016). Other examples of the previous mentioned problems include the war in Iraq, the Balkans, Libya and the Caucasus. Many of these conflicts may perhaps overturn from regional to global conflict, which complicate the solution of global problems. We cannot rely on the fact that development automatically leads itself to a positive way of solving them, for example, through technology transfer. A realistic view of the world must consider the danger of deep contradictions of contemporary civilization anchored in Sustainable Development Goals. It is necessary to mobilize the self-increasing forces of humanity so that the only conceivable perspective, if we put humans as the highest value over patents and licenses, becomes the only real prospect. Optimism can be based on several historical examples where reason and the sound sense of people have managed to cope with some problems because its logic is based on a practical premise of possible development.

Both of these features play a crucial role in the global project «Transforming Our World: the 2030 Agenda for Sustainable Development». As we mentioned before, the lack of understanding and trust among the authorities of the public sector, the business sphere and society has been the main reason for the political instability and expansion of military conflicts in developing countries in recent years. This instability results in the increased migration processes, which are a severe issue not only for developing countries but also for their economically successful partners. Under the influence of globalization, there is a new organization of social relations and linkages on the ground, of the entire capital space, of the allocation of production capacities, and the dynamics of individual local subsystems of the world economy. The emergence of new communication arteries, new transport networks and technologies, and the change in logistics systems creates new circumstances for the development of supply and distribution among nations. Globalization through technology transfer is creating a new phase of integration of the world economy, and the direct investment may be the driver of financial sector development (Wamboye \& Mookerjee, 2014).

Almost all innovative financing mechanisms and technological transfer combine private sector resources with public sector resources and expertise experiments (Ederer \& Manso, 2013). Due to globalization, required knowledge and experience are shared, and this sharing can bring benefits to society effectively and efficiently to the areas of social and environmental importance across the technological transfer and innovation process. Partial results have been already trackable. Two issues may limit the social benefits from innovating finance. One refers to the possibility that specific innovations may be designed to circumvent taxes and regulations. The second one refers to that to legal regulation and supervision should ensure that innovative financing instruments are sufficiently transparent and understandable for markets to work efficiently, and society to carry on benefitting from an ongoing modernization of finance and the financial system to avoid financial instability. Technological transfer and objective innovations should resolve the needs of modernization as well as the sustainable development goals of the nations. The unification of international patent law, which is so different in each context, would make it possible to find better ways to address the use of intellectual property.

\section{References}

Adhikari, H. P., Choi, W., \& Sah, N. B. (2017). That is what friends do: Employee friendliness and innovation. Journal of Economics and Business, 90, 65-76. doi: 10.1016/j.jeconbus.2016.10.004

Aerts, K., Kraft, K., \& Lang, J. (2015). Profit sharing and innovation. Industrial and Corporate Change, 24(6), 1377-1392. doi: 10.1093/icc/dtvoo9

Almario, F. (2018). Transferencia y negociación de tecnología. Programa de Innovación Facultad de Ciencias Pontificia Universidad Javeriana. Universidad Javeriana. http://www.cecolda.org.co/images/red/ negociacion.pdf

Archibugi, D., \& Michie, J. (1995). The globalisation of technology: A new taxonomy. Cambridge Journal of Economics, 19(1), 121-140. doi: 10.1093/oxfordjournals.cje.a035299

Balkin, D. B., \& Gomez-Mejia, L. R. (1984). Determinants of $\mathrm{R}$ and $\mathrm{D}$ compensation sStrategies in the high tech industry. Personnel Psychology, 37(4), 635650. doi: 10.1111/j.1744-6570.1984.tboo530.x 
Brander, J. A., \& Zhang, W. (2017). Employee relations and innovation: an empirical analysis using patent data. Economics of Innovation and New Technology, 26(4), 368-384. doi: 10.1080/10438599.2016.1202523

Commercial Code (C.C.). Codigo de comercio de Colombia. Decreto 410 de 1971. Retrieved November 3, 2018, from http://www.ccbuga.org.co/sites/default/files/decreto_ley_410_de_1971.pdf

d'Andria, D. (2016a). Taxation and incentives to innovate: A principal-agent approach. FinanzArchiv, 72(1), 96-123. doi: 10.1628/001522116Х14557023949337

d'Andria, D. (2016b). Why are researchers paid bonuses? On technology spillovers and market rivalry. Research Policy, 45(10), 2105-2112. doi: 10.1016/j. respol.2016.08.006

d'Andria, D., \& Savin, I. (2018). A win-win-win? Motivating innovation in a knowledge economy with tax incentives. Technological Forecasting and Social Change, 127, 38-56. doi: 10.1016/j. techfore.2017.05.030

Deutsches Patent und Markenamt. (2017). https://www. dpma.de/english/

Doucouliagos, C., \& Laroche, P. (2010). Unions, innovation, and technology adoption: New insights from the cross-country evidence (Working Paper). Deakin University, Department of Economics. https://econpapers.repec.org/paper/dkneconwp/ eco_5f2010_5f16.htm

Ederer, F. \& Manso, G., (2013). Is Pay for Performance Detrimental to Innovation?. Management Science, 59(7), 1496-1513. https://doi.org/10.1287/ mnsc.1120.1683

Edgar, B., Abouzeedan, A., Hedner, T., Maack, K., \& Lundqvist, M. (2013). Using scenario planning in regional development context: the challenges and opportunities. World Journal of Science, Technology and Sustainable Development, 10(2), 103-122. doi: 10.1108/20425941311323118

Essop, R., \& Hoque, M. E. (2018). The impact of emotional intelligence on employee motivation in the construction industry in South Africa. International Journal of Work Organisation and Emotion, 9(2), 125-138. doi: 10.1504/IJWOE.2018.093254

Fabbri, E. (2016). Strategic planning and foresight: The case of smart specialisation strategy in Tuscany. Foresight, 18(5), 491-508. doi: 10.1108/FS-06-20150036

Funtowicz, S. \& Ravetz, J. (1995). Planning and decision making in an uncertain world: the challenge of post-normal science. In T. Horlick-Jones, A. Amendola, \& R. Cassale (Eds.), Natural Risk and Civil Protection. 415-423. Chapman \& Hall.
Griffith, R., Miller, H., \& O’Connell, M. (2014). Ownership of Intellectual Property and Corporate Taxation. Journal of Public Economics, 112, 12-23. doi: 10.1016/j.jpubeco.2014.01.009

Guerrero, M. (2014). Los Contratos de Transferencia Internacional de Tecnología. América Latina, Estados Unidos y la Unión Europea. Editorial Universidad Externado de Colombia.

Iammarino, S., Sanna-Randaccio, F., \& Savona, M. (2009). The perception of obstacles to innovation. foreign multinationals and domestic firms in Italy. Revue D'économie Industrielle, (125), 75-104. doi: 10.400o/rei.3953

Imaz, M. \& Sheinbaum, C. (2017). Science and technology in the framework of the sustainable development goals. World Journal of Science, Technology and Sustainable Development, 14(1), 2-17. https://doi. org/10.1108/WJSTSD-04-2016-0030.

Instituto Nacional de Propiedad Industrial (INAPI) (2018). Frequently Asked Questions Industrial Property. https://www.inapi.cl/en/frequently-asked-questions/industrial-property

Instituto Nacional da Propriedade Industrial-INPI. (2018). Retrieved November 3, 2018, from http:// www.inpi.gov.br/

Intellectual Property Department, Hong Kong. (2017). Retrieved April 20, 2017, from http://www.ipd.gov. hk/eng/intellectual_property/ip_laws/patents. htm

Intellectual Property Office, Foreign and Commonwealth Office, Government Legal Department, Attorney General's Office, Department for Business, Energy and Industrial Strategy, Ministry of Justice, Civil Procedure Rule Committee, HM Courts and Tribunals Service, \& Parole Board. (2017). Intellectual property: Law and practice. Retrieved April 20, 2017, from https://www.gov.uk/topic/intellectual-property/law-practice

Intellectual Property Rights Information \& Assistance (2019). Mexico Protecting IP. Retrieved October 17, 2019, from https://www.stopfakes.gov/article?i$\mathrm{d}=$ Mexico-ProtectingIP

Irani, Z. (2010). Investment evaluation within project management: An information systems perspective. Journal of the Operational Research Society, 61(6), 917-928. doi: 10.1057/jors.2010.10

Jaakson, K., \& Kallaste, E. (2016). Who uses employee financial participation in an adverse environment? The case of Estonia. Economic and Industrial Democracy, 37(3), 449-467. doi: 10.1177/0143831X14546240

Japan. Patent Act (Act No. 121 of 13 April 1959, as amended up to 2006) (n.d.). WIPO Lex. Retrieved April 
20, 2017, from: http://www.wipo.int/wipolex/en/ text.jsp?file_id=188310

Jiang, G., \& Hamilton, R. D. (2010). Corporate governance and ownership structure and new technology acquisition: Empirical evidence of Indian manufacturing firms. International Journal of Technology Intelligence and Planning, 6(4), 326. doi: 10.1504/ IJTIP.2010.038228

Jurisdictions. (2017). Retrieved April 20, 2017, from Jurisdictions Hogan Lovells website: http://limegreenip.hoganlovells.com/jurisdictions

Kabadaki, K. (1994). Rural African women and development. Social Development Issues, 16(2), 23-35.

Kaufmann, R. (1995). The economic multiplier of environmental life support: Can capital substitute for a degraded environment? Ecological Economics 12(1), 67-79. doi: 10.1016/o921-80o9(94)ooo26-R

Maas, K., \& Rosendaal, S. (2016). Sustainability Targets in Executive Remuneration: Targets, Time Frame, Country and Sector Specification. Business Strategy and the Environment, 25(6), 390-401. doi: 10.1002/bse.188o

Madlock, P. E., \& Sexton, S. (2015). An Application of Motivating Language Theory in Mexican Organizations. International Journal of Business Communication, 52(3), 255-272. doi: 10.1177/2329488415572783

Molero, J., \& Garcia, A. (2008). The innovative activity of foreign subsidiaries in the Spanish Innovation System: An evaluation of their impact from a sectoral taxonomy approach. Technovation, 28(11), 739-757. doi: 10.1016/j.technovation.2008.03.005

Nepal, M. P., Park, M., \& Son, B. (2006). Effects of schedule pressure on construction performance. Journal of Construction Engineering and Management, 132, 182-188.

Oficina Española de Patentes y Marcas. (n.d.). Invenciones. Retrieved April 20, 2017, from https:// www.oepm.es/es/Invenciones_Menu/index.html

Oliveira, E. H. da S. (2015). Place branding in strategic spatial planning: A content analysis of development plans, strategic initiatives and policy documents for Portugal 2014-2020. Journal of Place Management and Development, 8(1), 23-50. doi: 10.1108/JPMD-12-2014-0031

Ortiz, J., Malagón, S. \& Masera, O. (2015). Ecotecnología y sustentabilidad: una aproximación para el Sur global. Interdisciplina, 3(7), 193-215.doi: 10.22201/ ceiich.24485705e.2015.7.52391_

Patent Law - France. (2017). Retrieved 20 April 2017, from https://iclg.com/practice-areas/patentslaws-and-regulations/france

Patent law in Italy. (2017). UfficioBrevetti.it Retrieved 20 April 2017, from http://ufficiobrevetti.it/en/ guides/patents/
Postępowanie sporne - Urząd Patentowy Rzeczypospolitej Polskiej. (2017). Retrieved 20 April 2017, from https://uprp.gov.pl/pl/przedmioty-ochrony/inne/ postepowanie-sporne

Ratiu, C., \& Anderson, B. B. (2014). The identity crisis of sustainable development. World Journal of Science, Technology and Sustainable Development, 11(1), 4-15. doi: 10.1108/WJSTSD-08-2013-0033

Rose, T. M., \& Manley, K. (2010). Client recommendations for financial incentives on construction projects. Engineering, Construction and Architectural Management, 17(3), 252-267.

Rotmans, J. \& Loorbach, D. (2009). Complexity and Transition Management. Journal of Industrial Ecology, 13(2), 184-196. doi: 10.1111/j.15309290.2009.00116.x

Russian Federation. Patent Law of Russian Federation No. 3517-1 of September 23, 1992 (as amended by Federal Law No. 22-FZ of February 7, 2003). (n.d.). WIPOLex. Retrieved 20 April 2017, from http:// www.wipo.int/wipolex/en/text.jsp?file_id=189120

Saadi, S., \& Djebabra, M. (2015). The contribution of the ERA to the selection of the environmental indicators and to the allowance of the environmental objectives. World Journal of Science, Technology and Sustainable Development, 12(1), 61-78. doi: 10.1108/WJSTSD-08-2014-0022

Scholz, R. \& Steiner, G. (2015). Transdisciplinarity at the crossroads. Sustainability Science, 10(4), 521-526. doi: 10.1007/s11625-015-0338-o

State Intellectual Property Office of The P.R.C. (2017). http://english.sipo.gov.cn/laws/relatedlaws/

Straškraba, M. (1993). Ecotechnology as a new means for environmental management. Ecological Engineering, 2(4), 311-331. doi: 10.1016/09258574(93)90001-V

Thiher, A. (2001). Fiction Rivals Science: The French Novel from Balzac to Proust. University of Missouri Press.

United States Patent and Trademark Office (2017). Laws, regulations, policies, procedures, guidance and training. https://www.uspto.gov/patent/lawsregulations-policies-procedures-guidance-andtraining

Varadzin, F. (2013). Mezinárodní ekonomie: (Teorie světového hospodářství). Professional Publishing.

Vico, G. (1984). The New Science of Giambattista Vico(T. Bergin \& M. Fisch, Trans). Cornell University Press. (Original work published 1744)

Wamboye, E., \& Mookerjee, R. (2014). Financial development and manufactured exports: the African experience. International Journal of Economic Policy in Emerging Economies, 7(1), 22-34. doi: 10.1504/ IJEPEE.2014.059898 
WIPO - World Intellectual Property Organization. (2018). http://www.wipo.int/portal/en/index.html

Zapatrina, I. (2016). Sustainable Development Goals for Developing Economies and Public-Private Partnership. European Procurement \& Public Private Partnership Law Review, 11(1), 39-45.

Zhang, B., \& Morris, J. L. (2014). High-performance work systems and organizational performance: testing the mediation role of employee outcomes using evidence from PR China. The International Journal of Human Resource Management, 25(1), 68-90. doi: 10.1080/09585192.2013.781524 